\title{
"Exploring fast moving consumer goods (FMCG) small, medium and micro enterprises manufacturers' need for innovation to achieve growth"
}

\begin{tabular}{|c|c|}
\hline AUTHORS & $\begin{array}{l}\text { Lawrence Mpele Lekhanya D https://orcid.org/0000-0002-9104-963X } \\
\text { Nze Grace Olajumoke } \\
\text { Dorasamy Nirmala }\end{array}$ \\
\hline ARTICLE INFO & $\begin{array}{l}\text { Lawrence Mpele Lekhanya, Nze Grace Olajumoke and Dorasamy Nirmala } \\
\text { (2017). Exploring fast moving consumer goods (FMCG) small, medium and micro } \\
\text { enterprises manufacturers' need for innovation to achieve growth. Environmental } \\
\text { Economics, } 8(2), 8-16 \text {. doi:10.21511/ee.08(2).2017.01 }\end{array}$ \\
\hline DOI & http://dx.doi.org/10.21511/ee.08(2).2017.01 \\
\hline RELEASED ON & Thursday, 20 April 2017 \\
\hline RECEIVED ON & Monday, 19 December 2016 \\
\hline ACCEPTED ON & Wednesday, 08 February 2017 \\
\hline LICENSE & $\begin{array}{l}(c))_{\text {EY-NG }} \\
\text { This work is licensed under a Creative Commons Attribution-NonCommercial } 4.0 \\
\text { International License }\end{array}$ \\
\hline JOURNAL & "Environmental Economics" \\
\hline ISSN PRINT & $1998-6041$ \\
\hline ISSN ONLINE & $1998-605 X$ \\
\hline PUBLISHER & LLC "Consulting Publishing Company "Business Perspectives" \\
\hline FOUNDER & LLC "Consulting Publishing Company "Business Perspectives" \\
\hline
\end{tabular}

NUMBER OF REFERENCES

23

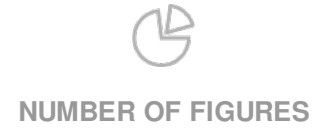

0

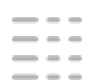

NUMBER OF TABLES

20

(C) The author(s) 2022. This publication is an open access article. 
Lawrence Mpele Lekhanya (South Africa), Nze Grace Olajumoke (South Africa), Dorasamy Nirmala (South Africa)

\title{
Exploring fast moving consumer goods (FMCG) small, medium and micro enterprises manufacturers' need for innovation to achieve growth
}

\begin{abstract}
The purpose of this paper is to explore the level of innovation in the fast moving consumer goods (FMCG) manufacturing SMMEs sectors and identify the causes of low innovation in the industry, and examine to what extent these factors influence the effectiveness of SMMEs manufacturers innovation strategies, as well as to design a new innovation strategic approach to overcome innovation problems in the economic growth of fast moving consumer goods SMMEs manufacturers. The study is aimed at determining the level of innovation and factors contributing to low innovation in fast moving consumer goods (FMCG) SMMEs manufacturers hindering their economic performance. Mixed approach of quantitative and qualitative questionnaire was used for primary data collection. Sample consists of 120 FMCG manufacturing SMMEs. Statistical Package for Social Sciences (SPSS) (23.0) was employed for data analysis. Findings of the study will be presented with figures and diagrams. This study will be a useful tool for general public and relevant stakeholders in this sector.
\end{abstract}

Keywords: innovation, small, medium and micro enterprises, manufacturers, fast moving consumer goods (FMCG).

JEL Classification: O31, L60, L26.

Received on: $19^{\text {th }}$ of December, 2016.

Accepted on: $8^{\text {th }}$ of February, 2017.

\section{Introduction}

SMMEs are the key basis of fiscal intensification in developed and developing countries similarly. Mwarari (2013) stated that these entities play an essential role in the job creation, the mitigation of lack and, generally, enabling the economy. Microenterprises (a division of the extensive small, medium and micro enterprises (SMME)) are anticipated to be a significant medium in dealing with the problems of employment creation, sustainable economic intensification, impartial allocation of income and the general motivation of trade and industry improvement in South Africa (Chandra, Moorty, Nganou, Rajaratnam and Schaefer, 2001). However, regardless of the aforementioned contributions of microenterprises to the retail sector in South Africa, these sectors experience shortfalls at a hugely unsuccessful pace (Olawale, 2014).

Nieman and Nieuwenhuizen (2009) acknowledge difficulties encountered by SMMEs in South Africa such as lack of training and education; restricted access

C Lawrence Mpele Lekhanya, Nze Grace Olajumoke, Dorasamy Nirmala, 2017.

Lawrence Mpele Lekhanya, Department of Public management \& Economics, Durban University of Technology, South Africa.

Nze Grace Olajumoke, Department of Entrepreneurial studies \& Management, Durban University of Technology, South Africa.

Dorasamy Nirmala, Professor, Department of Public management \& Economics, Durban University of Technology, South Africa.

This is an Open Access article, distributed under the terms of the Creative Commons Attribution-NonCommercial 4.0 International license, which permits re-use, distribution, and reproduction, provided the materials aren't used for commercial purposes and the original work is properly cited. to monetary resources; inaccessibility to markets; inefficiency of sustenance organizations; lack of suitable expertise; and deprivation of access to supplementary resources, like human resources. Joshua and Peter (2010) also acknowledge that SMME growth is significantly confined by a number of factors such as deficiency of access to suitable expertise; restricted contact with global markets; the existence of laws, regulations and rules that hamper the improvement of the sector; frail institutional ability; inefficient administration skills and training; and funding.

\section{Problem statements}

The Department of Trade and Industry (2012) revealed the soaring extent of the inability for small, medium and micro enterprises (SMMEs) to develop in South Africa. The reason for this stems from factors such as inefficient administrative proficiencies; deprivation of help from government; lack of training and inadequate access to proper technology (Nkonde, 2012). Statistics South Africa's First Quarterly Report (2012) states that entrepreneurship in the informal sector in South Africa is dormant and, in diverse areas, is deteriorating. Informal sector recruitment remains unstable, with three consecutive quarterly reductions experienced since the third quarter of 2011.

The questions addressed in this study are:

- What are the factors that influence the level of innovation in South African fast moving consumer goods (FMCG) manufacturing SMMEs?

- What can South African fast moving consumer goods (FMCG) SMME manufacturers do to be more innovative in their industry? 
- What can be done to improve innovation in South African fast moving consumer goods (FMCG) SMME manufacturers?

\section{Aims and objectives of the study}

Aims. The general aims of this research are to explore the level of innovation in South African fast moving consumer goods (FMCG) manufacturing SMMEs; examine factors that influence innovation in the industry by investigating the strategies in use, taking cognizance of KwaZulu-Natal (KZN) FMCG SMME manufacturers; and discover the reasons for low innovation in the industry.

Objectives. In support of the major aims, the following fundamental objectives are also addressed:

- to identify critical factors influencing the innovation of South African fast moving consumer goods (FMCG) SMME manufacturers to achieve growth;

- to examine the extent to which these factors influence the effectiveness of SMME manufacturers innovation strategies; and

- to design a new strategic approach innovation to overcome innovation problems in South African fast moving consumer goods (FMCG) SMME manufacturers.

\section{Literature review}

3.1. Definitions of innovation. An innovation, as defined by the Oslo Manual, is the implementation of new or significantly improved products (goods or services), or processes, a new marketing method, or a new organizational method in business practices, workplace, organization or external relation (OECD, 2005). In addition, innovation can be described as doing things differently and better. This is common in growing firms, as they continue to seek new and cost effective ways of doing work (Chimucheka, 2013). Nieman and Pretorius (2004) supported that growing firms thrive on innovation. Nieman and Pretorious (2004) stated that innovation enable the company to improve on a new product or a new way of production, to improve market size, increase sales and help the company to compete globally. Innovation is a critical factor in the manufacturing sector, which is a continuous process to become competitive in the market (Mustapha, 2010). Mustapha (2010) further explains that innovation has an important role to play in conceiving the idea of a new product, designing the product, defining the process, formulating the strategy and adapting to the technology. In addition, he says that innovation not only helps the growth and the development of manufacturing sector, but also plays a vital role in the economic stability of a country.
Innovation is viewed as a means by which new knowledge is transformed into economic growth (Alessandra, Klaciba and Christian, 2013). Alessandra, Klaciba and Christian (2013) further support the argument that more innovation generates more growth, which promotes higher levels of employment and job creation. Furthermore, Alessandra, Klaciba and Christian (2013) confirm that innovation has a positive effect on the rate of firm growth, and that innovation is of crucial importance for high-growth firms. Sheshinski, Strom and Baumol (2007) state that a major source of the growth miracle of the past two centuries is the surge of innovation. Hence, innovation has long been considered as the key factor for the survival, growth and development of small, micro and medium-sized enterprises (SMMEs) (Agupusi, 2007). Innovation is regarded as an instrument that propels economic development and is equally important for SMMEs and large enterprises in all parts of the world (Muhammed, Mohd and Halim, 2012).

\subsection{Definitions of small, micro and medium} enterprises (SMMEs). According to South Africa National Small Business Act 102 of 1996, SMMEs are devided into:

- survivalist enterprises: the profits produced are smaller than the least revenue regulation or the insufficiency limit. This explanation is described as pre-entrepreneurial, and it comprises road-side sellers, dealers and smallscale farmers (in practice, survivalist enterprises are often described as an element of microenterprises);

- microenterprises: the income is less than the VAT registration maximum value (that is, R150 000 for each year). These enterprises typically are frequently short of procedures in aspects of listing. They comprise, for example, spaza shops, minibus taxis and family businesses. They recruit no more than five employees;

- very small enterprises: these are ventures that recruit less than 10 workers, apart from mining, electricity, manufacturing and construction sectors, in which the number is 20 employees. These ventures function in the reserved market and have admittance to expertise;

- small enterprises: the highest limit is 50 workers. Small enterprises are normally more familiar than very small enterprises and display added complex business acumen;

- medium enterprises: the highest number of workers is 100 or 200 for the mining, electricity, manufacturing and construction 
sectors. These enterprises are repeatedly characterized by the devolution of authority to a further administrative level.

\subsection{Contribution of SMMEs to South African} economic development. SMMEs are the major basis that determines trade and industry expansion in industrial and emergent countries evenly (Mwarari, 2013). Mwarari (2013) further explains that in the United States, for instance, SMEs are believed to supply 67 percent of job opportunity and 61 percent of industrialized segment productivity. In South Africa, an anticipated number of 3,830,511 small, medium and micro enterprises (SMMEs) are presently in operation (Bruwer, 2012). Bruwer (2012) further explains that these entities make a very important contribution to establishing employment, mitigation of scarcity, as well as general enhancement of the economy. Despite the problems encountered by SMMEs in South Africa, literature reveals some of the input and significance of SMMEs to the economy. It is debatable that most of the commercial action occurs in SMMEs (Chimucheka, 2013). SMMEs from 97 percent of all enterprises in South Africa generate 35 percent of the gross domestic product (GDP) (Nieman and Nieuwenhuizen, 2009).

\subsection{Theoretical framework on manufacturing} SMMEs. Small, micro and medium sized enterprises (SMMEs) are undeniably essential to sustaining strong economic growth. However, to maintain their performance in the long term is a big problem (Aylin, Patrizia, Paola and Umit, 2013). SMMEs consist of a very diverse group of business owners at various levels of skill, assets, complexity and expansion orientation (Aripov and Hokyun, 2014). Aripov and Hokyun (2014) explain further that several countries have diverse definitions for SMMEs in the manufacturing and service sector and may exempt firms from particular industries or from firms that have shareholdings by parent companies. In this study, the theory of manufacturing SMMEs' framework is used to indicate any class of configuration or method that collaborates innovation and growth in the FMCG SMME manufacturing sector. In order to survive in today's competitive business environment, manufacturing firms, especially small, micro, and medium enterprises (SMMEs), are required to join efforts and to collaborate and share the needed knowledge, capabilities, capital and vital mass to grow innovative businesses and deliver higher quality and multifaceted products (Carneiro, Cunha, Fereira and Shamsuzzoha, 2013). A manufacturing strategy method has to do with both administrative and executive problems such as membership, contact, project supervision and point of entry (Malin, Kristina and Mats, 2014).
3.5. The importance of innovation in the SMME manufacturing sector. The small, micro and medium enterprise (SMME) sector plays an important role in the fiscal growth and development of any economy (Chimucheka, 2013). It adds to the goals of economic growth, economic empowerment, employment provision and poverty reduction in different ways (DTI, 2003). Small, micro and medium enterprises (SMMEs) in the manufacturing sector make a major contribution to economic development (DTI, 2012). However, most research into innovation management in the manufacturing sector has centred on large establishments (Mile, 2010). SMMEs in the manufacturing sector are also faced with bigger competition from cheaper manufactured products from countries such as China and India (Bessant and Tidd, 2007) and are consequently struggling to develop suitable strategies for competing with them.

Innovation is seen as a way by which innovative knowledge is transformed into economic growth (Alessandra, Klaciba and Christian, 2013). Alessandra, Klaciba and Christian (2013) support the argument that more innovation brings more growth, which promotes higher levels of employment and job creation. Furthermore, Alessandra, Klaciba and Christian (2013) confirm that innovation has a constructive effect on the rate of firm growth, and that innovation is of vital importance for high growth firms. Sheshinski, Strom and Baumol (2007) state that the major source of the growth sensation of the past two centuries is the surge of innovation. Hence, innovation has long been seen as the major factor for the survival, growth and development of small, micro and medium-sized enterprises (SMMEs) (Terziovski, 2010).

3.6. Challenges faced by SMMEs in achieving innovation in South Africa. The soaring failure rate of SMMEs is high compared to large-scale business. In the United States of America, roughly 2 400 small businesses commence, while 2100 shut down on a daily basis, and big enterprises are prone to continue and remain in business rather than small businesses (Baumback, 1985). In South Africa, the failure rate recorded for SMMEs is projected and estimated between $70 \%$ and $80 \%$, with an associated cost of R117 246, which makes SMME failure rate estimated to be in surplus of R68 million larger than a 4 year period (Van Eeden, Viviers and Venter, 2002). Hence, calls for all SMMEs to be more innovative in the products they offer to customers.

Investigations revealed that South African SMMEs add about 35\% to the National Gross Domestic Product (NGDP) (Adeniran and Kelvin, 2012). 
Adeniran and Kelvin (2012) argued further that SMMEs seem very important in the aspect of assistance in fiscal development; improvement of innovative goods; and scientific growth alongside competitive benefits, which makes nearly all of these SMMEs face problems, which include variations in expertise, inventive goods and customers wants, in addition to the aspiration of staying elastic. Boysana and Watson (2011) found that the dawdling expansion pace is accredited partially to deficiency in the support that small, medium and micro enterprises (SMMEs) obtain from financial sectors, along with their own internal challenges. Boysana and Watson (2011) discovered that the major frequent challenges affecting industry expansion are deficiency of official information, a deficiency of results plus broadened information for enterprise acumen.

\section{Methodology}

The study was conducted in different places in KwaZulu-Natal areas, which include Durban (Umbilo, Umgeni and Pinetown) and Pietermaritzburg province of KwaZulu-Natal. A comprehensive literature survey was conducted and used as sources of which involve 20 set of questions to get empirical data for this survey. A closed-ended questionnaire with 5 Likert scale were distributed to the SMMEs owners/managers business premises with the aid of research assistants. Prior appointments were made through telephone. The respondents were given 14 days to complete a questionnaire. Also, interviews with 5 experts were also conducted. Data were purely quantitative, and were analyzed by using Statistical Package for the Social Sciences (SPSS) program (version) 23.0 to test the significance of the results and later presented in the tables.

\section{Summary of key questions}

Question 1: South Africa government policies induce high cost of imported machinery and raw materials to support growth and productivity in the manufacturing firms.

Question 2: Skill and training form part of the prerequisite for companies to achieve innovation and growth.

Question 3: Adoption of manufacturing and innovation strategy captures the attention and loyalty of consumers in the South African FMCG manufacturers SMMEs.

Question 4: South African FMCG SMMEs offer different consumer products with innovative features and benefits.

Question 5: FMCG manufacturing SMMEs sector in South Africa has the capabilities of offering innovative consumer products in the context of globalization and high competition.
Question 6: The present level of innovation in South African FMCG manufacturers SMMEs is high.

Question 7: FMCG manufacturing SMMEs in South Africa give importance to innovation in the process of product designing and manufacturing.

Question 8: Company leaders/managers/supervisors encourage new ideas of innovation by creating a tolerant environment for innovation.

Question 9: Lack of financing, skills and knowledge and education are factors affecting innovation in FMCG manufacturing SMMEs in KwaZulu-Natal.

Question 10: High cost or complex procedures to register or defend patents is one of the problems of innovation in KwaZulu-Natal FMCG manufacturing SMMEs.

Question 11: Lack of information on the part of employers on how to satisfy consumers' interest contributes to low innovation in the industry.

Question 12: Lack of technological know-how and human capital problems can limit innovation in FMCG manufacturing SMMEs in KwaZulu-Natal.

Question 13: Difficulty in accessing finance for $R \& D$ is one of the problems facing innovation in South African FMCG manufacturing SMMEs.

Question 14: Government laws and regulations, new entrants' threats and protocols are impediments to innovation growth in South African FMCG manufacturing SMMEs.

Question 15: Effective supply chain management can lead to innovation in South African FMCG manufacturing SMMEs.

Question 16: Lack of branding of products can lead to low innovation in FMCG manufacturing SMMEs in KwaZulu-Natal.

Question 17: Government's encouragement and support from various lending institutions can lead to innovation growth in FMCG manufacturing SMMEs in South Africa.

Question 18: Small, micro and medium enterprises (SMMEs) contribute to the economic growth of the country.

Question 19: Due to failure attributable to low innovation in the sector, less than $20 \%$ of SMMEs operate for less than four years and less than 0.5 percent of SMMEs are doing business for more than 25 years in South Africa. This is due to lack of innovation in the industry.

Question 20: Innovation is considered important for the survival and growth of small, micro and medium enterprises in South Africa. 


\section{Research findings}

Table 1. South African government policies

\begin{tabular}{|l|c|c|c|c|}
\hline & $\begin{array}{c}\text { Valid } \\
\text { frequency }\end{array}$ & Percentage & $\begin{array}{c}\text { Valid } \\
\text { percentage }\end{array}$ & $\begin{array}{c}\text { Cumulative } \\
\text { percentage }\end{array}$ \\
\hline $\begin{array}{l}\text { Strongly } \\
\text { Disagree }\end{array}$ & 5 & 4.8 & 4.8 & 4.8 \\
\hline Disagree & 3 & 2.9 & 2.9 & 7.6 \\
\hline Neutral & 11 & 10.5 & 10.5 & 18.1 \\
\hline $\begin{array}{l}\text { Strongly } \\
\text { agree }\end{array}$ & 57 & 54.3 & 54.3 & 72.4 \\
\hline Agree & 29 & 27.6 & 27.6 & 100.0 \\
\hline Total & 105 & 100.0 & 100.0 & \\
\hline
\end{tabular}

As shown in Table 1, $5(5 \%)$ of the respondents replied strongly disagree; $3(3 \%)$ said disagree; 11 (11\%) said neutral; $57(54 \%)$ said strongly agree; and 29 (28\%) said agree. Thus, the result of the survey revealed that many of the respondents strongly agree that South African government policies induce high costs of imported machinery and raw materials to support growth and productivity in the manufacturing firms.

Table 2. Skills and training to achieve growth

\begin{tabular}{|l|c|c|c|c|}
\hline & $\begin{array}{c}\text { Valid } \\
\text { frequency }\end{array}$ & Percentage & $\begin{array}{c}\text { Valid } \\
\text { percentage }\end{array}$ & $\begin{array}{c}\text { Cumulative } \\
\text { percentage }\end{array}$ \\
\hline $\begin{array}{l}\text { Strongly } \\
\text { Disagree }\end{array}$ & 4 & 3.8 & 3.8 & 3.8 \\
\hline Disagree & 2 & 1.9 & 1.9 & 5.7 \\
\hline Neutral & 1 & 1.0 & 1.0 & 6.7 \\
\hline $\begin{array}{l}\text { Strongly } \\
\text { agree }\end{array}$ & 66 & 62.9 & 62.9 & 69.5 \\
\hline Agree & 32 & 30.5 & 30.5 & 100.0 \\
\hline Total & 105 & 100.0 & 100.0 & \\
\hline
\end{tabular}

The results, as shown in Table 2, state that $4(4 \%)$ of the respondents replied strongly disagree; $2(2 \%)$ said disagree; 1 (1\%) said neutral; $66(63 \%)$ said strongly agree; and $32(31 \%)$ said agree. The result of the survey, thus, shows that many of the respondents strongly agree that skills and training form part of the pre-requisite for companies to achieve innovation and growth.

Table 3. Customers' loyalty

\begin{tabular}{|l|c|c|c|c|}
\hline & $\begin{array}{c}\text { Valid } \\
\text { frequency }\end{array}$ & Percentage & $\begin{array}{c}\text { Valid } \\
\text { percentage }\end{array}$ & $\begin{array}{c}\text { Cumulative } \\
\text { percentage }\end{array}$ \\
\hline Disagree & 5 & 4.8 & 4.8 & 4.8 \\
\hline Neutral & 5 & 4.8 & 4.8 & 9.5 \\
\hline $\begin{array}{l}\text { Strongly } \\
\text { agree }\end{array}$ & 56 & 53.3 & 53.3 & 62.9 \\
\hline Agree & 39 & 37.1 & 37.1 & 100.0 \\
\hline Total & 105 & 100.0 & 100.0 & \\
\hline
\end{tabular}

The results, as shown in Table 3, reveal that $5(5 \%)$ of the respondents replied strongly disagree; $5(5 \%)$ said disagree; 56 (53\%) said neutral; 39 (37\%) said strongly agree; and 105 (100\%) said agree. The result of the survey, thus, shows that many of the respondents strongly agree that skills and training form part of the pre-requisite for companies to achieve innovation and growth.

Table 4. Innovative features and benefits

\begin{tabular}{|l|c|c|c|c|}
\hline & $\begin{array}{c}\text { Valid } \\
\text { frequency }\end{array}$ & Percentage & $\begin{array}{c}\text { Valid } \\
\text { percentage }\end{array}$ & $\begin{array}{c}\text { Cumulative } \\
\text { percentage }\end{array}$ \\
\hline $\begin{array}{l}\text { Strongly } \\
\text { Disagree }\end{array}$ & 19 & 18.1 & 18.1 & 18.1 \\
\hline Disagree & 27 & 25.7 & 25.7 & 43.8 \\
\hline Neutral & 20 & 19.0 & 19.0 & 62.9 \\
\hline $\begin{array}{l}\text { Strongly } \\
\text { agree }\end{array}$ & 23 & 21.9 & 21.9 & 84.8 \\
\hline Agree & 16 & 15.2 & 15.2 & 100.0 \\
\hline Total & 105 & 100.0 & 100.0 & \\
\hline
\end{tabular}

The results, as shown in Table 4, reveal that 19 (19\%) of the respondents replied strongly disagree; 27 (26\%) answered disagree; 20 (19\%) said neutral; and $16(15 \%)$ said agree. The result of the survey revealed that many of the respondents strongly agree that South African FMCG SMMEs offer different consumer products with innovative features and benefits.

Table 5. Innovative consumer products

\begin{tabular}{|l|c|c|c|c|}
\hline & $\begin{array}{c}\text { Valid } \\
\text { frequency }\end{array}$ & Percentage & $\begin{array}{c}\text { Valid } \\
\text { percentage }\end{array}$ & $\begin{array}{c}\text { Cumulative } \\
\text { percentage }\end{array}$ \\
\hline $\begin{array}{l}\text { Strongly } \\
\text { Disagree }\end{array}$ & 8 & 7.6 & 7.6 & 7.6 \\
\hline Disagree & 36 & 34.3 & 34.3 & 41.9 \\
\hline Neutral & 13 & 12.4 & 12.4 & 54.3 \\
\hline $\begin{array}{l}\text { Strongly } \\
\text { agree }\end{array}$ & 33 & 31.4 & 31.4 & 85.7 \\
\hline Agree & 15 & 14.3 & 14.3 & 100.0 \\
\hline Total & 105 & 100.0 & 100.0 & \\
\hline
\end{tabular}

The results as shown in Table 5, reveal that $8(8 \%)$ of the respondents replied strongly disagree; 36 (34\%) said disagree; 13 (13\%) replied neutral; 33 $(32 \%)$ answered strongly agree; and 15 (14\%) replied agree. Thus, the result of the survey revealed that most of the respondents disagree on the FMCG SMME sector's capabilities of offering innovative consumer products in the context of globalization and high competition.

Table 6. Levels of innovation in South African FMCG SMME manufacturers

\begin{tabular}{|l|c|c|c|c|}
\hline & $\begin{array}{c}\text { Valid } \\
\text { frequency }\end{array}$ & Percentage & $\begin{array}{c}\text { Valid } \\
\text { percentage }\end{array}$ & $\begin{array}{c}\text { Cumulative } \\
\text { percentage }\end{array}$ \\
\hline $\begin{array}{l}\text { Strongly } \\
\text { Disagree }\end{array}$ & 31 & 29.5 & 29.5 & 29.5 \\
\hline Disagree & 45 & 42.9 & 42.9 & 72.4 \\
\hline Neutral & 6 & 5.7 & 5.7 & 78.1 \\
\hline $\begin{array}{l}\text { Strongly } \\
\text { agree }\end{array}$ & 11 & 10.5 & 10.5 & 88.6 \\
\hline Agree & 12 & 11.4 & 11.4 & 100.0 \\
\hline Total & 105 & 100.0 & 100.0 & \\
\hline
\end{tabular}


As shown in Table 6, the results revealed that 31 $(30 \%)$ of the respondents replied strongly disagree; 45 (43\%) answered disagree; $6(6 \%)$ said neutral; 11 (11\%) said strongly agree; and 12 (11\%) replied agree. The result revealed that most of the respondents disagree on the notion that the present level of innovation in South African FMCG manufacturer SMMEs is high.

Table 7. Importance of innovation in the process of product designing and manufacturing

\begin{tabular}{|l|c|c|c|c|}
\hline & $\begin{array}{c}\text { Valid } \\
\text { frequency }\end{array}$ & Percentage & $\begin{array}{c}\text { Valid } \\
\text { percentage }\end{array}$ & $\begin{array}{c}\text { Cumulative } \\
\text { percentage }\end{array}$ \\
\hline $\begin{array}{l}\text { Strongly } \\
\text { Disagree }\end{array}$ & 7 & 6.7 & 6.7 & 6.7 \\
\hline Disagree & 46 & 43.8 & 43.8 & 50.5 \\
\hline Neutral & 13 & 12.4 & 12.4 & 62.9 \\
\hline $\begin{array}{l}\text { Strongly } \\
\text { agree }\end{array}$ & 25 & 23.8 & 23.8 & 86.7 \\
\hline Agree & 14 & 13.3 & 13.3 & 100.0 \\
\hline Total & 105 & 100.0 & 100.0 & \\
\hline
\end{tabular}

As shown in Table 7, the results revealed that 7 (7\%) of the respondents replied strongly disagree; 48 (44\%) said disagree; 13 (13\%) replied neutral; 25 (24\%) said strongly agree; and $14(13 \%)$ replied agree. From the results of the survey revealed, a majority of the respondents disagree that the FMCG manufacturing SMMEs in South Africa give importance to innovation in the process of product designing and manufacturing.

Table 8. Creating a tolerant environment for innovation

\begin{tabular}{|l|c|c|c|c|}
\hline & $\begin{array}{c}\text { Valid } \\
\text { frequency }\end{array}$ & Percentage & $\begin{array}{c}\text { Valid } \\
\text { percentage }\end{array}$ & $\begin{array}{c}\text { Cumulative } \\
\text { percentage }\end{array}$ \\
\hline $\begin{array}{l}\text { Strongly } \\
\text { Disagree }\end{array}$ & 10 & 9.5 & 9.5 & 9.5 \\
\hline Disagree & 34 & 32.4 & 32.4 & 41.9 \\
\hline Neutral & 27 & 25.7 & 25.7 & 67.6 \\
\hline $\begin{array}{l}\text { Strongly } \\
\text { agree }\end{array}$ & 19 & 18.1 & 18.1 & 85.7 \\
\hline Agree & 15 & 14.3 & 14.3 & 100.0 \\
\hline Total & 105 & 100.0 & 100.0 & \\
\hline
\end{tabular}

As shown in Table 8, the results of the survey indicate that $10(10 \%)$ of the respondents replied strongly disagree; 34 (32\%) replied disagree; 27 (26\%) answered neutral; 19 (18\%) said strongly agree; and $15(14 \%)$ replied agree. The result of the survey, hence, revealed that a majority of the respondents disagree that the company leaders/managers/supervisors encourage new ideas of innovation by creating a tolerant environment for innovation.
Table 9. Lack of financing and skills

\begin{tabular}{|l|c|c|c|c|}
\hline & $\begin{array}{c}\text { Valid } \\
\text { frequency }\end{array}$ & Percentage & $\begin{array}{c}\text { Valid } \\
\text { percentage }\end{array}$ & $\begin{array}{c}\text { Cumulative } \\
\text { percentage }\end{array}$ \\
\hline Disagree & 2 & 1.9 & 1.9 & 1.9 \\
\hline Neutral & 2 & 1.9 & 1.9 & 3.8 \\
\hline $\begin{array}{l}\text { Strongly } \\
\text { agree }\end{array}$ & 76 & 72.4 & 72.4 & 76.2 \\
\hline Agree & 25 & 23.8 & 23.8 & 100.0 \\
\hline Total & 105 & 100.0 & 100.0 & \\
\hline
\end{tabular}

The results, as shown in Table 9, reveal that $2(2 \%)$ of the respondents replied disagree; $2(2 \%)$ said neutral; 76 (72\%) answered strongly agree; and 25 (24\%) agree. The results of the survey, thus, revealed that most people strongly agree that lack of financing, skills and knowledge and education are factors affecting innovation in FMCG manufacturing SMMEs in KwaZulu-Natal.

Table 10. High costs or complex procedures

\begin{tabular}{|l|c|c|c|c|}
\hline & $\begin{array}{c}\text { Valid } \\
\text { frequency }\end{array}$ & Percentage & $\begin{array}{c}\text { Valid } \\
\text { percentage }\end{array}$ & $\begin{array}{c}\text { Cumulative } \\
\text { percentage }\end{array}$ \\
\hline Disagree & 2 & 1.9 & 1.9 & 1.9 \\
\hline Neutral & 3 & 2.9 & 2.9 & 4.8 \\
\hline $\begin{array}{l}\text { Strongly } \\
\text { agree }\end{array}$ & 66 & 62.9 & 62.9 & 67.6 \\
\hline Agree & 34 & 32.4 & 32.4 & 100.0 \\
\hline Total & 105 & 100.0 & 100.0 & \\
\hline
\end{tabular}

The results, as shown in Table 10, reveal that $2(2 \%)$ of the respondents replied disagree; $3(3 \%)$ answered neutral; 66 (63\%) said strongly agree; and $34(32 \%)$ replied agree. The results of the survey clearly show that the majority of the respondents strongly agree that high costs or complex procedures to register or defend patents are problems for innovation in FMCG manufacturing SMMEs in KwaZulu-Natal.

Table 11. Lack of information on the part of employer

\begin{tabular}{|l|c|c|c|c|}
\hline & $\begin{array}{c}\text { Valid } \\
\text { frequency }\end{array}$ & Percentage & $\begin{array}{c}\text { Valid } \\
\text { percentage }\end{array}$ & $\begin{array}{c}\text { Cumulative } \\
\text { percentage }\end{array}$ \\
\hline Neutral & 2 & 1.9 & 1.9 & 1.9 \\
\hline $\begin{array}{l}\text { Strongly } \\
\text { agree }\end{array}$ & 64 & 61.0 & 61.0 & 62.9 \\
\hline Agree & 39 & 37.1 & 37.1 & 100.0 \\
\hline Total & 105 & 100.0 & 100.0 & \\
\hline
\end{tabular}

The results, as revealed in Table 11, show that 2 (2\%) of the respondents replied neutral; 64 (61\%) said strongly agree; and 39 (37\%) said agree. The results of the survey showed that a majority of the respondents strongly agree that lack of information on the part of employers on how to satisfy consumers' interests contributes to low innovation in the industry. 
Table 12. Lack of technological know-how

\begin{tabular}{|l|c|c|c|c|}
\hline & $\begin{array}{c}\text { Valid } \\
\text { frequency }\end{array}$ & Percentage & $\begin{array}{c}\text { Valid } \\
\text { percentage }\end{array}$ & $\begin{array}{c}\text { Cumulative } \\
\text { percentage }\end{array}$ \\
\hline Disagree & 1 & 1.0 & 1.0 & 1.0 \\
\hline Neutral & 4 & 3.8 & 3.8 & 4.8 \\
\hline $\begin{array}{l}\text { Strongly } \\
\text { agree }\end{array}$ & 56 & 53.3 & 53.3 & 58.1 \\
\hline Agree & 44 & 41.9 & 41.9 & 100.0 \\
\hline Total & 105 & 100.0 & 100.0 & \\
\hline
\end{tabular}

The results in Table 12 show that $1(1 \%)$ of the respondents replied disagree; $4(4 \%)$ answered neutral; 56 (53\%) answered strongly agree; and 44 $(42 \%)$ said agree. The results of the survey showed that many of the respondents strongly agree that lack of technological know-how and human capital problems limit innovation in FMCG manufacturing SMMEs in KwaZulu-Natal.

Table 13. Finance issues

\begin{tabular}{|l|c|c|c|c|}
\hline & $\begin{array}{c}\text { Valid } \\
\text { frequency }\end{array}$ & Percentage & $\begin{array}{c}\text { Valid } \\
\text { percentage }\end{array}$ & $\begin{array}{c}\text { Cumulative } \\
\text { percentage }\end{array}$ \\
\hline Disagree & 3 & 2.9 & 2.9 & 2.9 \\
\hline Neutral & 3 & 2.9 & 2.9 & 5.7 \\
\hline $\begin{array}{l}\text { Strongly } \\
\text { agree }\end{array}$ & 62 & 59.0 & 59.0 & 64.8 \\
\hline Agree & 37 & 35.2 & 35.2 & 100.0 \\
\hline Total & 105 & 100.0 & 100.0 & \\
\hline
\end{tabular}

The results, as shown in Table 13, reveal that $3(3 \%)$ of the respondents disagree; 3 (3\%) answered neutral; 62 (59\%) said strongly agree; and 37 (35\%) responded agree. The results of the survey, therefore, revealed that a majority of the respondents strongly agree that difficulty in accessing finance for $R \& D$ is one of the problems facing innovation in South African FMCG manufacturing SMMEs in KwaZulu-Natal.

Table 14. Government laws and regulations issues

\begin{tabular}{|l|c|c|c|c|}
\hline & $\begin{array}{c}\text { Valid } \\
\text { frequency }\end{array}$ & Percentage & $\begin{array}{c}\text { Valid } \\
\text { percentage }\end{array}$ & $\begin{array}{c}\text { Cumulative } \\
\text { percentage }\end{array}$ \\
\hline $\begin{array}{l}\text { Strongly } \\
\text { Disagree }\end{array}$ & 1 & 1.0 & 1.0 & 1.0 \\
\hline Neutral & 6 & 5.7 & 5.7 & 6.7 \\
\hline $\begin{array}{l}\text { Strongly } \\
\text { agree }\end{array}$ & 61 & 58.1 & 58.1 & 64.8 \\
\hline Agree & 37 & 35.2 & 35.2 & 100.0 \\
\hline Total & 105 & 100.0 & 100.0 & \\
\hline
\end{tabular}

The results, as shown in Table 14, reveal that $1(1 \%)$ of the respondents replied strongly disagree; $6(6 \%)$ said neutral; 61 (58\%) replied strongly agree; and 37 $(35 \%)$ answered agree. The results of the survey showed that a majority of the respondents strongly agree that government laws and regulations, new entrant threats and protocols are some of impediments to innovation growth in South African FMCG manufacturing SMMEs.
Table 15. Effective supply chain management

\begin{tabular}{|l|c|c|c|c|}
\hline & $\begin{array}{c}\text { Valid } \\
\text { frequency }\end{array}$ & Percentage & $\begin{array}{c}\text { Valid } \\
\text { percentage }\end{array}$ & $\begin{array}{c}\text { Cumulative } \\
\text { percentage }\end{array}$ \\
\hline $\begin{array}{l}\text { Strongly } \\
\text { Disagree }\end{array}$ & 1 & 1.0 & 1.0 & 1.0 \\
\hline Neutral & 17 & 16.2 & 16.2 & 17.1 \\
\hline $\begin{array}{l}\text { Strongly } \\
\text { agree }\end{array}$ & 47 & 44.8 & 44.8 & 61.9 \\
\hline Agree & 40 & 38.1 & 38.1 & 100.0 \\
\hline Total & 105 & 100.0 & 100.0 & \\
\hline
\end{tabular}

The results, as shown in Table 15, reveal that $1(1 \%)$ of the respondents replied strongly disagree; 17 (16\%) said neutral; 47 (45\%) replied strongly agree; and 40 (38\%) said agree. The results of the survey, therefore, showed that most respondents strongly agree that effective supply chain management led to innovation in South African FMCG manufacturing SMMEs.

Table 16. Lack of product brand name

\begin{tabular}{|l|c|c|c|c|}
\hline & $\begin{array}{c}\text { Valid } \\
\text { frequency }\end{array}$ & Percentage & $\begin{array}{c}\text { Valid } \\
\text { percentage }\end{array}$ & $\begin{array}{c}\text { Cumulative } \\
\text { percentage }\end{array}$ \\
\hline $\begin{array}{l}\text { Strongly } \\
\text { Disagree }\end{array}$ & 5 & 4.8 & 4.8 & 4.8 \\
\hline Disagree & 6 & 5.7 & 5.7 & 10.5 \\
\hline Neutral & 12 & 11.4 & 11.4 & 21.9 \\
\hline $\begin{array}{l}\text { Strongly } \\
\text { agree }\end{array}$ & 44 & 41.9 & 41.9 & 63.8 \\
\hline Agree & 38 & 36.2 & 36.2 & 100.0 \\
\hline Total & 105 & 100.0 & 100.0 & \\
\hline
\end{tabular}

The results, as shown in Table 16, reveal that $5(5 \%)$ of the respondents replied strongly disagree; $6(6 \%)$ said disagree; 12 (11\%) replied neutral; 44 (42\%) answered strongly agree; and $38(36 \%)$ said agree. The results of the survey, therefore, show that a majority of the respondents strongly agree that lack of product brand name leads to low innovation in FMCG manufacturing SMMEs in KwaZulu-Natal.

Table 17. Issues of government support

\begin{tabular}{|l|c|c|c|c|}
\hline & $\begin{array}{c}\text { Valid } \\
\text { frequency }\end{array}$ & Percentage & $\begin{array}{c}\text { Valid } \\
\text { percentage }\end{array}$ & $\begin{array}{c}\text { Cumulative } \\
\text { percentage }\end{array}$ \\
\hline $\begin{array}{l}\text { Strongly } \\
\text { Disagree }\end{array}$ & 5 & 4.8 & 4.8 & 4.8 \\
\hline Disagree & 10 & 9.5 & 9.5 & 14.3 \\
\hline Neutral & 6 & 5.7 & 5.7 & 20.0 \\
\hline $\begin{array}{l}\text { Strongly } \\
\text { agree }\end{array}$ & 56 & 53.3 & 53.3 & 73.3 \\
\hline Agree & 28 & 26.7 & 26.7 & 100.0 \\
\hline Total & 105 & 100.0 & 100.0 & \\
\hline
\end{tabular}

The results, as shown in Table 17, reveal that $5(5 \%)$ of the respondents strongly disagree; $10(10 \%)$ disagree; $6(6 \%)$ said neutral; $56(53 \%)$ replied strongly agree; and $28(27 \%)$ replied agree. The results of the survey, therefore, show that majority of respondents strongly agree that government encouragement and support from various lending institutions lead to innovation growth in FMCG manufacturing SMMEs in South Africa. 
Table 18. Issue of growth of the SMME industry

\begin{tabular}{|l|c|c|c|c|}
\hline & $\begin{array}{c}\text { Valid } \\
\text { frequency }\end{array}$ & Percentage & $\begin{array}{c}\text { Valid } \\
\text { percentage }\end{array}$ & $\begin{array}{c}\text { Cumulative } \\
\text { percentage }\end{array}$ \\
\hline Disagree & 1 & 1.0 & 1.0 & 1.0 \\
\hline Neutral & 2 & 1.9 & 1.9 & 2.9 \\
\hline $\begin{array}{l}\text { Strongly } \\
\text { agree }\end{array}$ & 81 & 77.1 & 77.1 & 80.0 \\
\hline Agree & 21 & 20.0 & 20.0 & 100.0 \\
\hline Total & 105 & 100.0 & 100.0 & \\
\hline
\end{tabular}

The results, as shown in Table 18 reveal that $1(1 \%)$ of the respondents said disagree; 2 (2\%) replied neutral; 81 (77\%) said strongly agree; and $21(20 \%)$ answered agree. It is, thus, revealed from the results of the survey that most of the respondents strongly agree that small, micro and medium enterprises contribute to the economic growth of the country.

Table 19. Issue of failure in SMME manufacturers

\begin{tabular}{|l|c|c|c|c|}
\hline & $\begin{array}{c}\text { Valid } \\
\text { frequency }\end{array}$ & Percentage & $\begin{array}{c}\text { Valid } \\
\text { percentage }\end{array}$ & $\begin{array}{c}\text { Cumulative } \\
\text { percentage }\end{array}$ \\
\hline Neutral & 4 & 3.8 & 3.8 & 3.8 \\
\hline $\begin{array}{l}\text { Strongly } \\
\text { agree }\end{array}$ & 75 & 71.4 & 71.4 & 75.2 \\
\hline Agree & 26 & 24.8 & 24.8 & 100.0 \\
\hline Total & 105 & 100.0 & 100.0 & \\
\hline
\end{tabular}

According to Table 19, the results reveal that 4 (4\%) of the respondents are neutral to the question; 75 $(71 \%)$ said strongly agree; and $26(25 \%)$ answered agree. It is, therefore, concluded by the results of the survey that a majority of the respondents strongly agree that less than $20 \%$ of SMMEs operate for less than four years and less than $0.5 \%$ of SMMEs are doing business for more than 25 years in South Africa due to failure attributable to low innovation in the sector.

Table 20. Importance of innovation

\begin{tabular}{|l|c|c|c|c|}
\hline & $\begin{array}{c}\text { Valid } \\
\text { frequency }\end{array}$ & Percentage & $\begin{array}{c}\text { Valid } \\
\text { percentage }\end{array}$ & $\begin{array}{c}\text { Cumulative } \\
\text { percentage }\end{array}$ \\
\hline Neutral & 2 & 1.9 & 1.9 & 1.9 \\
\hline $\begin{array}{l}\text { Strongly } \\
\text { agree }\end{array}$ & 65 & 61.9 & 61.9 & 63.8 \\
\hline Agree & 38 & 36.2 & 36.2 & 100.0 \\
\hline Total & 105 & 100.0 & 100.0 & \\
\hline
\end{tabular}

The results, as shown in Table 20, reveal that 4 (4\%) of the respondents are neutral to the question; 75 (71\%) said strongly agree; and $26(25 \%)$ answered agree. It is, therefore, concluded by the results of the survey that a majority of the respondents strongly agree that less than $20 \%$ of SMMEs operate for less than four years and less than $0.5 \%$ of SMMEs are doing business for more than 25 years in South Africa due to failure attributable to low innovation in the sector.

\section{Limitations}

This study did not cover large number of the respondents. Therefore, generalization of these results should be done with care. Due to the complexity of South African geographical profile, further research needs to be done to cover more fast moving consumer goods (FMCG) small, micro and medium entrepreneurs (SMMEs) manufacturing sectors.

\section{Research implications}

The findings of this study revealed that the level of innovation in FMCG SMMEs manufacturing sector in KwaZulu-Natal needs to be improved. Therefore, the practical implications of this study will benefit all South African FMCG SMMEs manufacturing sectors, by providing clear understanding of critical factors influencing the rate of innovation in South Africa with specific reference to KwaZulu-Natal.

\section{Conclusions}

Based on the findings, this study concludes that the level of innovation in South African FMCG SMMEs manufacturers is low and there is the feeling among the respondents that the level of innovation needs special skills and improvements, with regards to restructuring the manufacturing process and strategy; improving the skills development and training of workers; improvement in research and development areas; and increasing finance skills, knowledge and education.

\section{References}

1. Adeniran, T. V., \& Kevin, A. (2012). Investigating the Dynamic Capabilities and Competitive Advantage of South African SMEs. African Journal of Business Management, 6(11), 4088-4099.

2. Agupusi, P. (2007). Small Business Development and Poverty Alleviation in Alexander, South Africa. Paper prepared for the second meeting of the society for the study of Economic Inequality, Berlin, July.

3. Alessandra, C., Klaciba, H., \& Christian, L. B. (2013). On the firm growth and innovation: some new empirical perspectives, using French CIS (1992-2004). Structural change and economic dynamics, 26(1), 14-26.

4. Aripov, J., \& Hokyun, S. (2014). Factors Influencing e-Commerce adoption in Uzbekistan SMEs. Management Review. An International Journal, 9(2), 1-32.

5. Aylin, A., Patrizia, G., Paola, C., \& Umit, B. (2013). The Development of SME Managerial Practice for Effective Performance Management. Journal of Small Business and Enterprise Development, 20(1), 28-54.

6. Baumack, C. M. (1985). How to operate a small business. 7th edition, Englewood: Cliffs, New Jersey: PretenceHall.

7. Bessant, J., \& Tidd, J. (2007). Innovation and entrepreneurship. Wiley: Chiechester, UK. 
8. Boysana, M. \& Watson, L. (2011). Factors that hinder the growth of small businesses in South African townships. European Business Review, 23(6), 550-560.

9. Carneiro, L. M., Cunha, P., Fereira, P. S., \& Shamsuzzoha, A. (2013). Conceptual Framework for non-hierachical business networks for complex products design and manufacturing. Procedia, CIRP 7, 61-66.

10. Chandra, V., Moorty, L., Nganou, J., Rajaratnam, B., and Schaefer, K. (2001). Constraints to Growth and Employment in South Africa. Report No 2, World Bank.

11. Chimucheka, T. (2013). Overview and Performance of the SMMEs sector in South Africa. Mediterranean Journal of Social Sciences, 4(14), 783-795.

12. Department of Trade and Industry (DTI). (2012). White paper on National Strategy for the Development and Promotion of Small Business in South Africa. Pretoria Government Publications.

13. Malin, L., Kristina, S., \& Mats, W. (2014). Manufacturing Strategy Frameworks suitable for SMEs. Journal of Manufacturing Technology Management, 25(1), 7-26.

14. Mile, T. (2010). Innovation practice and its performance implications in small and medium enterprises (SMEs) in the manufacturing sector: A Resource- Based view. Strategic Management Journal, 31(1), 892-902.

15. Muhammed, H. H., Mohd, N. M. S., \& Halim, B. M. L. (2012). Relationship between Entrepreneurial Orientation, Firm Resources, SME Branding and Firm's Performance: Is Innovation the Missing Link? American Journal of Industrial and Business Management, 2, 153-159.

16. Mustapha, U. M. (2010). The Role of Product Design, Manufacturing Systems and Environmental Uncertainty in Nigeria Manufacturing Organizations. Engineering Doctorate (D-Eng). Retreived from www.usq.edu.au. Accessed on 10 October 2014.

17. Mwarari, M. M. (2013). Factors Influencing Listing of Kenyan SMEs in the Securities Market for Capital Raising Opportunities. European Journal ofManagement Sciences and Economics, 1(2), 99-115.

18. Nieman, G., Hough, J., \& Niewenhuizen, C. (2003). Entrepreneurship: A South African Perspective. Pretoria: Van Schaik.

19. Nieman, G. \& Pretorius, M. (2004). Managing Growth: A Guide for entrepreneurs. Cape Town: Juita and co. Ltd.

20. Nkonde, S. D. (2012). Information Asymmetry and Obstacles on SMMEs growth in the Rural areas of uThungulu District Municipality of KwaZulu-Natal. M. Commerce, University of Zululand. Retreived from http://uzspace.uzulu.ac.za. Accessed on 15 April 2014.

21. Statistics South Africa. (2012). Statistical release: Quarterly Labour Force Survey, Quarter 1, 2012. Retreived from https://www.statssa.gov.za/publications/P0211/P02111stQuarter2012.pdf. Accessed on 19 November, 2014.

22. Terziovski, M. (2010). Innovation practice and its performance implications in small and medium enterprises (SMEs) in the manufacturing sector: a resource-based review. Strategic Management Journal, 31(8), 892-902.

23. Van Eeden, S.,Viviers, E., \& Venter, D. (2002). The use of selected sources of non-financial assistance by small businesses: A South African Perspective. Retreived from https://sites.google.com/a/uca.edu/sbanc/home. Accessed on 4 March 2015. Edition, Hampshire, UK: South-Western, Cengage Learning. 